\title{
ルイス肺癌細胞皮下接種マウスモデルにおける clarithromycinのサイトカイン発現に及ぼす効果
}

\author{
Effects of Clarithromycin on Expression of Cytokine mRNA \\ in Spleen Cells of Mice Bearing Lewis Lung Carcinoma Cells
}

植田勝廣 · 三笠桂一・濱田 薫 $\cdot$ 坂本正洋・古西 満

前田光一・眞島利匡 $\cdot$ 喜多英二* $\cdot$ 成田亘啓

要旨：14員環マクロライドは, 抗菌活性以外に種々の作用を有する事が明らかにされた.今回, CAMのbiological response modifier(BRM)作用の検討の為, マウス肺癌皮下接種モデ ルを用い, $\mathrm{CAM}$ 投与による脾細胞での各種サイトカイン mRNA発現の変動を検討した。 方法はC57BL/6䧳マウスにLewis肺癌 $(\mathrm{LLC})$ 細胞を, $3 \times 10^{5}$ 個腹壁に皮下接種し, CAM は $10 \mathrm{mg} / \mathrm{kg}$ を連日投与した。腫瘍接種, 非接種群で, CAM投与, 非投与群を設定, 処置 14日後に犠牲死させ, 脾細胞を検体とし reverse transcriptase-assisted polymerase chain reaction(RT-PCR) 法で検討した。結果は腫瘍非接種でCAM投与の有無による差は認め ず, 腫瘍接種のCAM投与群で非投与群と比較しIL-4, 12, IFN- $\gamma$ の発現増強, IL-6の発 現低下を認めた.CAMは担癌宿主のサイトカインネットワークを制御している可能性が 推測された。

〔肺癌 $39(2): 117 \sim 124,1999$ 〕

Key words: Clarithromycin, Cytokine, Lung cancer, Animal model,

Reverse transcriptase-assisted polymerase chain reaction

\section{はじめに}

Clarithromycin ( CAM ) は erythromycin (EM) と同じ14員環マクロライド系の抗生物質で ある. 本剤の長期投与は緑膿菌による難治性慢 性気道感染を来たし呼吸不全に至る予後不良の 疾患であるびまん性汎細気管支炎などの慢性下 気道感染症の予後を一変した有効で安全な画期 的な治療法である ${ }^{1) ~ 7) . ~}$

本剂の有効性は起炎菌にかかわらず有効で, 特にマクロライド薬が抗菌力を有さない緑膿菌 感染に長期投与が有効である事から, 本剂の有

奈良県立医科大学第 2 内科

$*$

同

細菌学
効性の作用機序について抗菌活性以外への作用 の研究が始められた。

我々は本剂の長期投与がヒトやマウスでNatural Killer細胞活性 ${ }^{5), 8), 11)}$ や interleukin2.4 を進 させる ${ }^{9) \sim 11)}$, Ehrich ascites carcinomaや P388leukemia細胞を用いたマウス腫瘍モデルで $\mathrm{EM}$ が生存率を向上し, 腫瘍の増殖抑制を示す, およびこれらの活性がCAMでより強い事を見出 し ${ }^{12)}, \mathrm{CAM}$ が生体内で biological response $\operatorname{modifier}(\mathrm{BRM})$ 作用を発現し得る可能性を考之, 切除不能原発性非小細胞肺癌患者にCAM投与を 試み生存期間が有意に延長( ${ }^{13), 14)}$, 宿主要因の 改善が認められる事 ${ }^{15)}$ を報告した。 
Fig. 1. Protocol.

\begin{tabular}{l}
\hline $\begin{array}{c}\text { Lewis lung carcinoma cells }\left(3 \times 10^{5}\right) \\
\text { subcutaneous injection } \\
\text { day } 0\end{array}$ \\
$\begin{array}{c}\text { without tumor, with CAM } \Rightarrow \\
\text { without tumor, without CAM } \\
\text { with tumor, with CAM } \\
\text { with tumor, without CAM }\end{array}$ \\
$\begin{array}{l}\text { without tumor : not injected with tumor cells } \\
\text { with CAM : treated with CAM }\end{array}$ \\
$\begin{array}{l}\text { Each group } n=9 \\
\text { with tumor : injected with tumor cells }\end{array}$
\end{tabular}

今回, $\mathrm{CAM}$ の $\mathrm{BRM}$ 作用の検討のため, マウ スのルイス肺癌皮下接種モデルでCAM投与の各 種サイトカイン産生変動を reverse transcriptaseassisted polymerase chain reaction(RT$\mathrm{PCR})$ 法でmRNAレベルで検討したので報告す る.

\section{対象と方法}

実験にはC57BL/6雌SPFマウス (日本エスエル シ一社)にLewis肺癌 (LLC) 細胞 (理化学研究所) を, $3 \times 10^{5}$ 個腹壁に皮下接種したモデルを用いた。

腫瘍接種, 非接種両群にCAM投与群, 非投与 群を設け, 計 4 群のC $57 \mathrm{BL} / 6$ 雌マウスを腫瘍接 種日から 2 週後に犠牲死させ脾細胞中のIL-2,

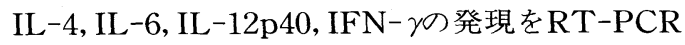
を用いて検討した(Fig. 1)。

クラリスロマイシン (CAM) は原末(ダイナボ ット社) $250 \mathrm{mg}$ を $99.5 \%$ エタール $1 \mathrm{ml}$ に懸濁, 蒸留水にて用事希䣋し, $10 \mathrm{mg} / \mathrm{kg}$ を胃ゾンデで 腫瘍接種日から $0.1 \mathrm{ml} ゙$ ず 14 日間連日強制経口投 与した。

各群 9 匹ずつ実験に使用し, 統計的処理はF検 定にて，検定を行った危険率で等分散である事 を確認した後, student's t testにて行った。

RT-PCR法は以下の手順で行った.

(1) TRizol（GIBCO BRL 社）を用いたAcid Guanidinium Thiocyanate-Phenol-Chloro- form (AGPC) 法で総RNAを抽出した.

(2)RNA量を0.08 $\mu \mathrm{g}$ に調整し, 逆転写酵素反応緩 衝液 (20mMTris- $\mathrm{HCl}$ ( $\mathrm{pH} 8.4$ ), 50mMKCl, 2.5 $\left.\mathrm{mMMgCl}_{2}, 10 \mathrm{mMDTT}\right)$ 及び $1 \mathrm{mM}$ のATP, dCTP, dGTP, dTTP, $0.25 \mu \mathrm{g} / \mu \mathrm{l}$ Oligo(dT) 12-18 primer と 10 単位RNase inhibitor と 50 単位 Reverse Transcriptase と混合し $43^{\circ} \mathrm{C}, 90$ 分反応 させcDNAに変換した。

(3) $4 \mu \mathrm{l}$ の cDNA をPCR 緩衝液 $(25 \mathrm{mMKCl}$,

$1.25 \mathrm{mMMgCl}_{2}, 10 \mathrm{mMTris}-\mathrm{HCl}(\mathrm{pH} 8.4)$ ), 2.5mMdATP, dCTP, dGTP, dTTP, $1 \mu$ Mprimer, 0.25単位Tag DNA polymeraseに混 合し，ミネラルオイルを重層，DNA Thermal cyclerで $94^{\circ} \mathrm{C} 1$ 分, $60^{\circ} \mathrm{C} 1$ 分, $72^{\circ} \mathrm{C} 1$ 分を 20 回行 った。

(4)PCR産物を1.5\%アガロースゲルで電気泳動を 行い(100V，35分)，エチジウムブロマイド染色 で確認し，123bpのladderでbandを同定した。 (5)Quantity One(PDi社)で各bandのOD值をも とに検討した。

実験に使用した特異的な primerの塩基配列は EBMLデータバンクに登録されている配列を用 い, RNA中のDNA混入による遺伝子增幅の可能 性を排除するため，少なくとも 1 つのイントロ ンをはさむエクソン部分からデザインしている (Fig. 2). 
Fig. 2. Primer.

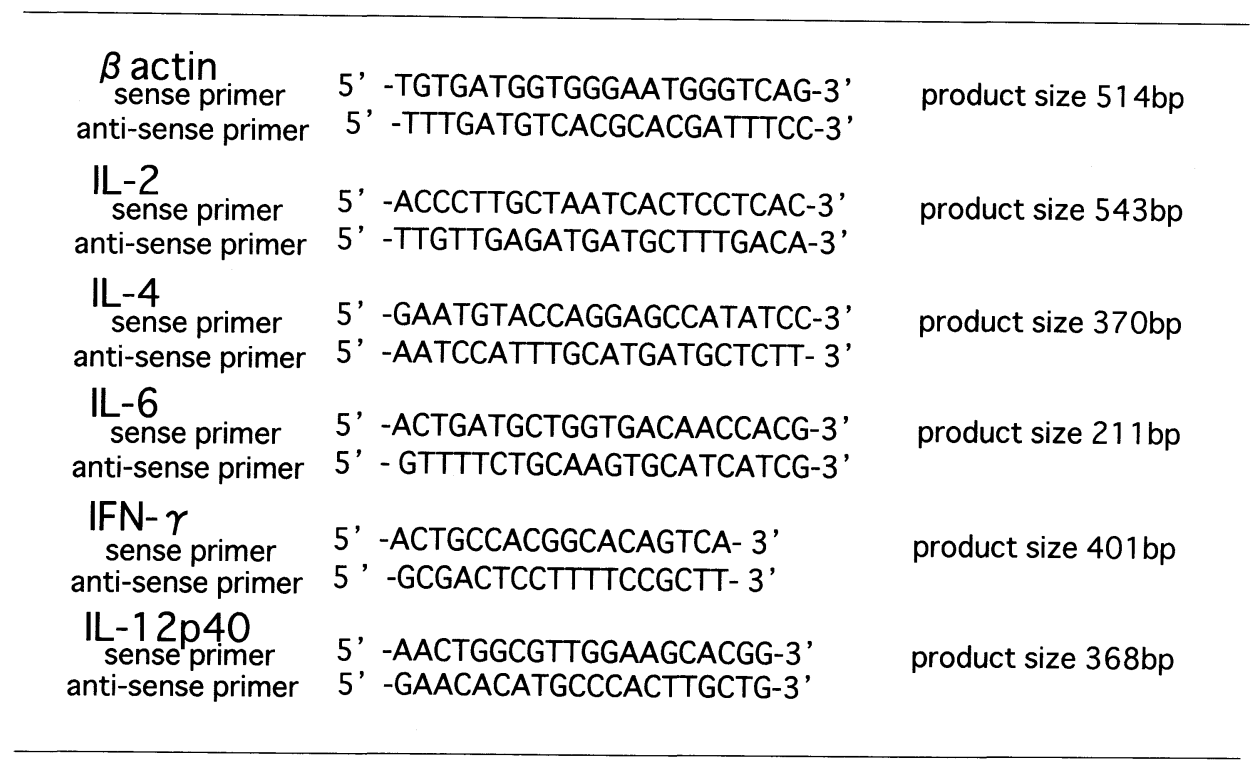

Fig. 3. Expression of IL-2 mRNA.

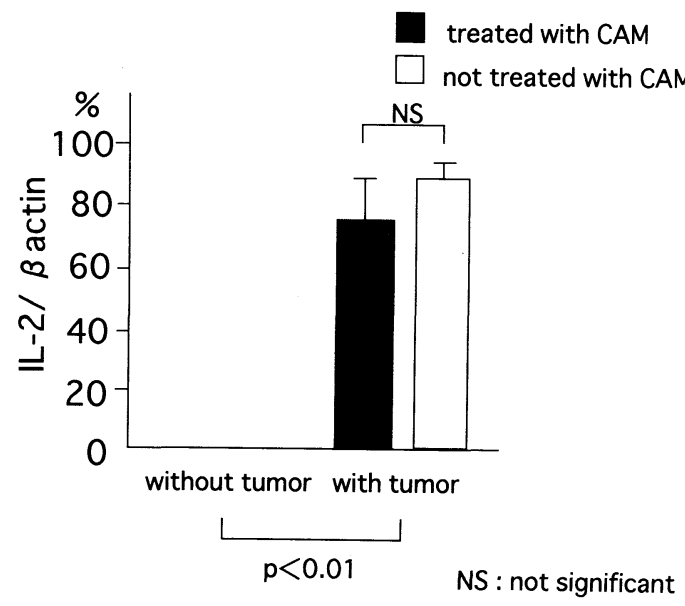

結 果

IL-2は腫瘍非接種群で発現は認めず，腫瘍接 種群では発現したがCAM投与, 非投与で差は認 めなかった(Fig. 3).

IL-4は腫瘍非接種群では発現を認めず, 腫瘍 接種群では発現し, CAM投与群は非投与群と比 較して有意に増強していた $(\mathrm{p}<0.05)$ (Fig. 4).

IL-6は腫瘍非接種群では発現を認めず, 腫瘍
Fig. 4. Expression of IL-4 mRNA.

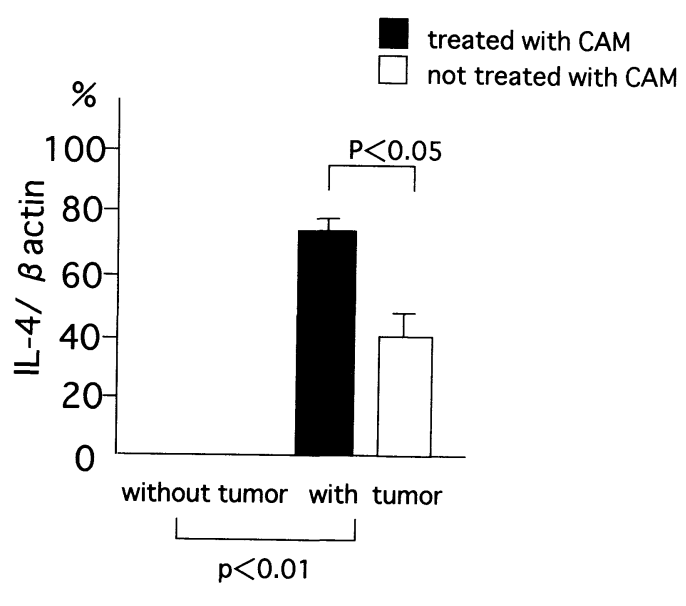

接種群では発現し,CAM投与群は非投与群と比 較して有意に低下していた $(\mathrm{p}<0.05)$ (Fig. 5).

IL-12p40は腫瘍非接種群では発現を認めず, 腫瘍接種群では発現し, CAM投与群は非投与群 と比較して有意に増強していた $(\mathrm{p}<0.05)$ (Fig. $6)$.

IFN- $\gamma$ も腫瘍非接種群では発現を認めず,腫瘍 接種群で発現しCAM投与群は非投与群と比較し 
Fig. 5. Expression of IL-6 mRNA.

treated with CAM not treated with CAM

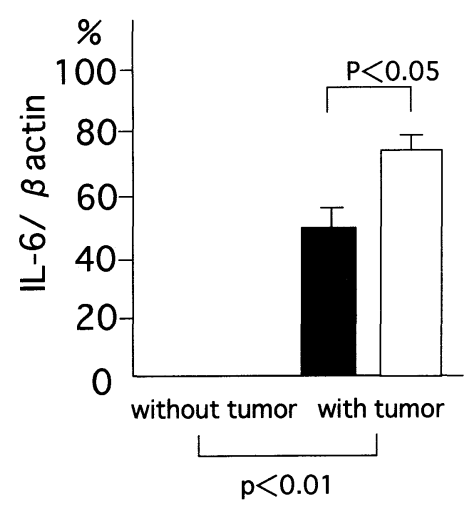

Fig. 7. Expression of IFN $-\gamma$ mRNA.

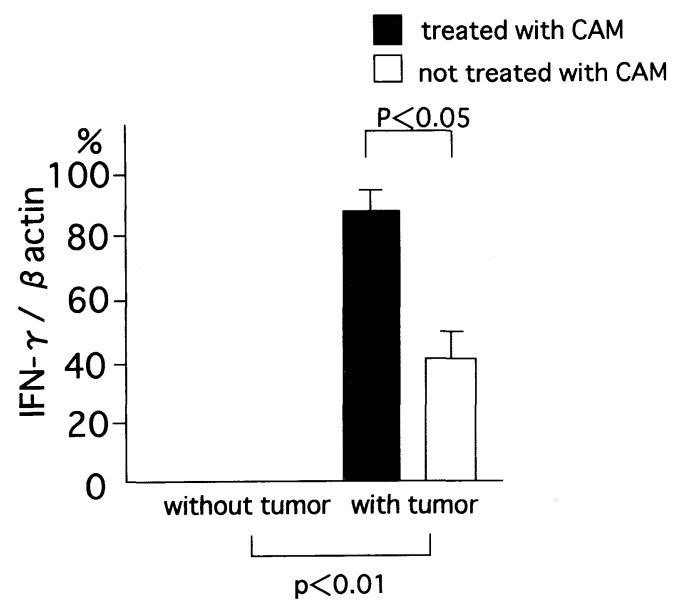

Fig. 6. Expression of IL-12p40 mRNA.

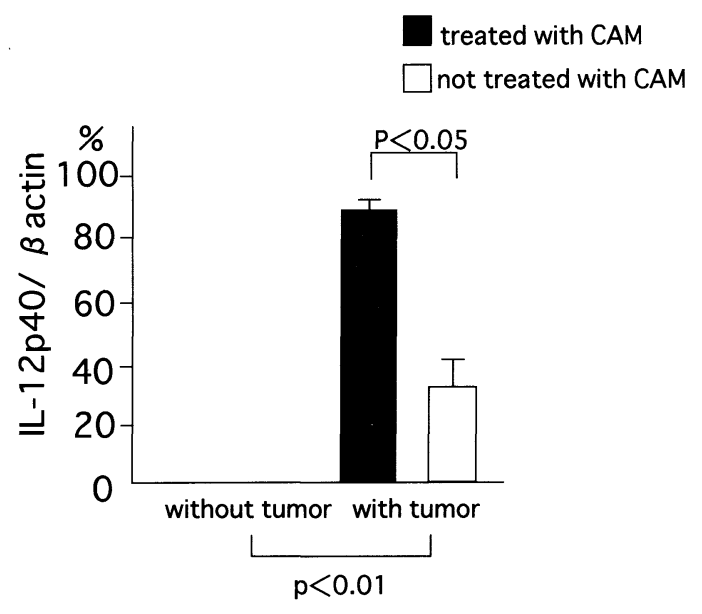

て有意に増強していた $(\mathrm{p}<0.05)$ (Fig. 7).

以上の結果をまとめると測定したすべてのサ イトカインは腫瘍非接種群でCAMの投与の有無 に関係なく発現しなかった。しかし，腫瘍接種 群で発現を認めた $(\mathrm{p}<0.01)$. そして, 腫瘍接種 群において, CAM投与群はCAM非投与群と比 較して, IL-4, IL-12p40, IFN- $\gamma$ の発現の増強 とIL-6の発現低下を認めた $(\mathrm{p}<0.05)($ Table 1$)$.

\section{考 察}

C57BL/6マウスにLewis肺癌を皮下接種したモ デルでCAM投与による脾細胞中のサイトカイン mRNAの変動を検討した。

Lewis肺癌細胞株は静脈内投与を行った場合, 高率に肺転移をもたらす細胞株として知られて

Table 1. Expression of cytokine mRNA.

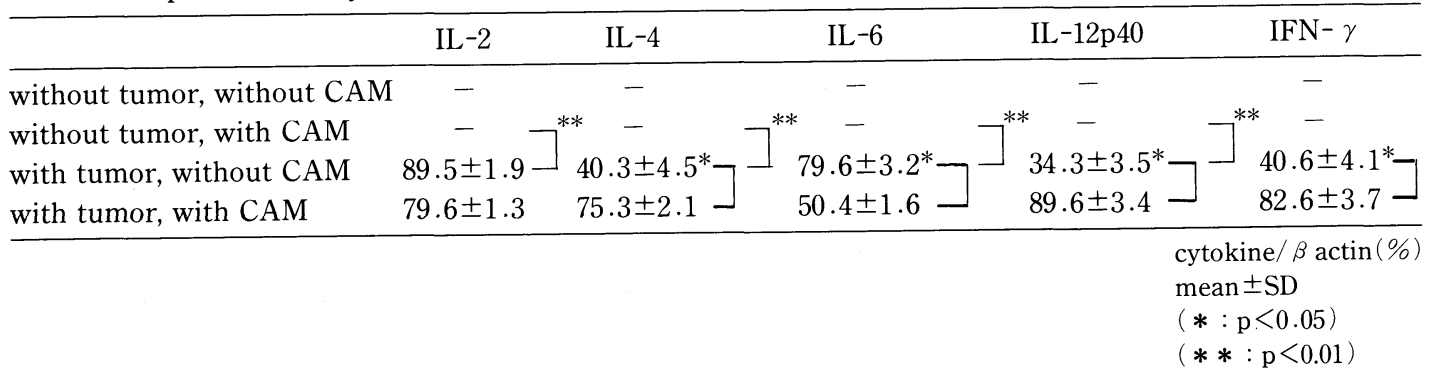


いる.濱田ら ${ }^{16)}$ は尾静脈からLewis肺癌細胞投与 を行ったBDF1マウスの肺転移結節の個数を調べ る強制転移モデルを用い, CAMの腫瘍肺転移抑 制効果を報告している。今回の実験では皮下に 接種したモデルを用いたため, 検体採取時, 胸 腔内及び腹腔内の臟器に転移結節を認めなかっ た。この動物モデルでは癌転移による臟器の障 害の影響は少なく, 担癌宿主における代謝異常 や免疫応答を比較的よく反映しうると考之られ る。また濱田ら ${ }^{16)}$ は今回使用した同じLewis肺癌 細胞皮下接種モデルで, 検体を採取した14日目 でCAMは腫瘍増殖抑制を認める事を報告してい る.今回の実験で検体採取する前に腫瘍径を測 定, 濱田ら ${ }^{16)}$ と同様に腫瘍体積を縦 $\times$ 横 $\times$ 高さ として検討すると, CAM投与群 $1840 \pm 663 \mathrm{~mm}^{3}$, 非投与群 $2770 \pm 1183 \mathrm{~mm}^{3}$ となり有意差を認め $(\mathrm{p}<$ 0.05), この動物モデルでのCAMの腫瘍増殖抑 制効果を確認しえた。

さて, 今回の研究では担癌刺激に対するCAM の影響を検討したが, 一般に担癌刺激とは, 生 体内に腫瘍細胞が出現する事による刺激と考之 られる.腫瘍が出現すると, Tリンパ球が腫瘍関 連抗原やある種の腫瘍表面物質と反応を抗こし 活性化され，様々なサイトカインを産生するよ うになる。産生されたサイトカインが更にマク ロファージやリンパ球を活性化させ腫瘍細胞を 傷害する反応が起こる.腫瘍関連抗原はCTLの 前駆細胞やへルパーT細胞に反応し活性化させる. 腫瘍細胞上のある種の表面物質は活性化したマ クロファージやNK細胞, LAK細胞と反応する. 活性化したへルパーT細胞が産生するサイトカイ ンは様々な効果を示す. IL-2, IL-4, IL-5, IL-

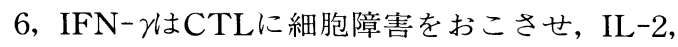
IL-12，IL-7などはLAK細胞を誘導し， IL-2, IL-12, IFN- $\gamma$ はNK細胞の働きを増強する。ま た腫瘍関連抗原に対する抗体が腫瘍細胞に結合 すると，そこにCTLやマクロファージがFCRと 結合して細胞障害をもたらす。様々な相互作用 により, 腫瘍細胞とCTL, マクロファージ, NK 細胞, LAK細胞等が反応をおこし細胞障害が惹 起される ${ }^{17)}$. 脾臓はリンパ球, マクロファージ を貯蔵している組織であり, リンパ球が再循環
している事を考えると，局所での反応が脾細胞 に何らかの影響を及ぼしていると考えられる。

今回の実験結果ではIL-2, IL-4, IL-6, IL$12 \mathrm{p} 40, \mathrm{IFN}-\gamma$ は腫瘍非接種群では発現を認めず 腫瘍接種群のみ発現を認めた。山本ら ${ }^{18)}$ は CSA1M線維肉腫を同系BALB/cマウスに移植し た系で担癌 $2 \sim 3$ 週のマウスの脾細胞全分画を in vitroで48時間培養すると, 正常マウス脾細胞 培養上清中には検出しなかったIL-2, IFN- $\gamma, \mathrm{TNF}$ 等のサイトカイン産生を, 上清中に強く検出す る事を報告し，担癌宿主で腫瘍が増殖をはじめ た初期に宿主抗腫瘍 T細胞は癌抗原刺激で,一旦 活性化されると述べている。本実験では脾臓は 腫瘍接種 2 週後採取しており，ルイス肺癌の担 癌刺激により脾細胞中のIL- $2, \mathrm{IL}-4, \mathrm{IL}-6, \mathrm{IL}-$ $12, \mathrm{IFN}-\gamma$ 発現が誘導されたと考えられる。 腫瘍非接種群はCAM投与, 非投与にかかわら ずサイトカインの発現は認められなかったが,

腫瘍接種群でCAM投与でIFN- $\gamma$, IL-4, IL-12 の発現増強, IL-6の発現低下がみられた。

前田ら ${ }^{19)}$ はalloxan静脈内投与により作製した 糖尿病マウスにzymosan腹腔内投与を行い, 腹 膜炎を惹起巳せた系で，糖尿病マウスのように 炎症作用が低下した状態では, CAMは炎症作用 を充進させ，逆に正常マウスでは炎症作用に抑 制的に作用する二面性がある事を報告し，この 作用をCAMのdual regulatory effectと呼んだ. 今回の検討でCAMは腫瘍接種マウスと非接種マ ウスとでサイトカイン産生に対する反応は異な り, CAMのサイトカイン産生に与える影響は正 常マウスでは認めず，担癌マウスでのみ認める 事が実証された。

一方，個々のサイトカインについては，IL-4 には抗腫瘍作用が知られており，その機序とし て腫瘍特異的なCTLを長期に誘導することが考 えられている ${ }^{20)}$. 我々はマウス腫瘍接種モデル でEMがIL-4産生を刺激しマクロファージやNK 細胞を活性化させ抗腫瘍効果を示す事をすでに 報告したが ${ }^{12)}$, 今回の結果では, 担癌マウスで CAMがIL-4の発現を増強している事から, CAM の腫瘍増殖抑制作用にIL-4を介したCTLの活性 化が関与する可能性が推察できる。次にIL-6は 
覀液質誘発に重要なサイトカインとして知られ ている21) 23). 我々は非小細胞肺癌患者でCAM 投与により悪液質が改善し血清中のIL-6が低下 する事 ${ }^{24)}$ またIL-6の変動と生存期間とが相関す る事 ${ }^{25)}$ 報告した。今回の実験でも，担癌マウ スでCAM投与でIL-6の発現が低下する事が実証 されている.IL-12はNK細胞やLAK細胞の活性 を高めるばかりでなくCD4陽性細胞に働きIFN㯆生を誘導し, CD8陽性細胞に働きCTLを活 性化させ, Macrophageを活性化する事が知られ

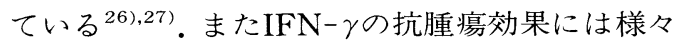

なものがあり，MHCクラス抗原，接着分子, IL$2 \mathrm{R}$ ，免疫グロブリン FcRなどの発現を増強する 事で抗腫瘍免疫応答が全般的に活性化される ${ }^{28)}$. 今回の実験では担癌マウスでCAM投与でIFN- $\gamma$, IL-12の発現が増強した。これらの結果からCAM はIFN- $\gamma, \mathrm{IL}-4, \mathrm{IL}-12 の$ 発現を増強し, IL-6の 発現を抑制する事で担癌宿主のリンパ球サブセッ トをTh1優位に誘導している可能性が考之られた。 今後の検討が必要であるがCAMは担癌状態で の各種サイトカイン産生を調節していると考え られる。

\section{文 献}

1) 澤木政好, 三上理一郎, 三笠桂一, 他 : 慢性下 気道感染症におけるErythromycin長期化学療法 の検討一第 1 報 Amoxicillin との対比. 感染症 誌 $60: 37-44,1986$.

2) 澤木政好, 三上理一郎, 三笠桂一, 他 : 慢性下 気道感染症におけるErythromycin長期化学療法 の検討一第 2 報 Pseudomonas感染例も含めて。 感染症誌 $60: 45-50,1986$.

3) 工藤翔二, 植竹健司, 萩原弘一, 他 : びまん性 沉細気管支炎に対するエリスロマイシン長期投 与の臨床効果に関する研究 -4 年間治療成績. 日胸疾会誌 $25 ： 632-643,1987$.

4) 三笠桂一, 澤木政好, 古西 満, 他 : 慢性下気 道感染症におけるErythromycin長期化学療法の 検討一第 3 報 投与期間 3 年以上の症例を中心 に一。感染症誌 $66: 561-567,1992$.

5) 三笠桂一，澤木政好，喜多英二，他：慢性下気 道感染症におけるErythromycin長期化学療法の 検討一第 4 報 EM無効例に対するClarithromycinの有用性について一。感染症誌 $66: 1097-$ 1104, 1992.

6）三笠桂一，澤木政好，喜多英二，他 : 慢性下気 道感染症におけるErythromycin長期化学療法の 検討一第 5 報 7 年以上の経過を観察しえた症 例について一。感染症誌 $66: 1390-1395,1992$.

7) 三笠桂一，澤木政好，喜多英二, 他 : 難治性緑 膿菌性慢性下気道感染症に対寸るErythromycin (EM) 長期療法の検討 - Quality of lifeからの観 点も含めて一. Chemotherapy $40: 647-653$, 1992.

8) 三笠桂一, 澤木政好, 古西 満, 他 : 慢性下気

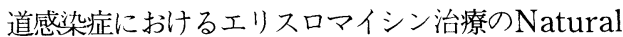
Killer細胞活性に与える影響について.感染症誌 $63: 811-815,1989$.

9）澤木政好，三笠桂一：慢性下気道感染症におけ るエリスロマイシン長期投与法. 化学療法の領 域 $6: 257-265,1990$.

10）前田光一, 澤木政好, 三笠桂一, 他: 慢性下気 道感染症におけるマクロライド薬投与における サイトカインの変動。日内会誌 $83: 133,1994$.

11) Kita E, Sawaki M, Nishikawa $F$, et al : Enhanced interleukin production after long term administration of erythromycin stearate. Pharmacol $41:$ 177-183, 1990.

12) Hamada K, Kita E, Sawaki M, et al : Antitumor effect of erythromycin in mice. Chemotherapy 41:59-69, 1995.

13) Mikasa K, Sawaki M, Kita E, et al:Significant survival benefit to patient with advanced non small cell lung cancer from treatment with clarithromycin. Chemotherapy 43, 288-296, 1997.

14）三笠桂一，澤木政好，喜多英二，他：肺癌治療 におけるbiological response modifierとしての マクロライド薬。日内会誌 $86: 100-107,1997$.

15）寺本正治, 三笠桂一, 澤木政好, 他：原発性肺 癌に対する clarithromycin長期投与の検討一臨 床的指標に与える影響について一. Chemotherapy $6: 451-458,1996$.

16）濱田 薫，坂本正洋，三笠桂一，他：マウス肺 癌細胞接種モデルにおけるCAM(clarithromycin) の抗腫瘍効果に対する検討. Japanese Journal 
of Antibiotics 50 : Suppl A, 28-31, 1996.

17) 矢田純一: 医系免疫学, 改訂 4 版, 中外医学社, 東京，388-405頁， 1995.

18) Yamamoto N, Zou JP, Li XF, et al : Regulatory mechanisms for production of IFNgamma and TNF by antitumor T cells or macrophages in the tumor-bearing state. $\mathrm{J}$ Immunol $154:$ 2281-2290, 1995.

19）前田光一,澤木政好,三笠桂一, 他 : clarithromycin の炎症反応に対するdual regulatory effect. 厚 生省特定疾患 びまん性肺疾患調查研究班 平 成 6 年度研究報告書 : 166-169, 1994 .

20) Tepper RI, Pattengalle PK, Leder P : Murine interleukin-4 displays potent anti-tumor activity in vivo. Cell $57:$ 503-512, 1989.

21）中嶋弘一, 平野俊夫：IL-6の基礎と臨床. 癌と 化学療法 18:505-514, 1991.

22) Strassman G, Fong M, Kenney JS, et al : Evidence for the involvement of interleukin 6 in experimental cancer cachexia. J Clin Invest 89 : 1681-1684, 1992.

23) Strassman G, Jacob CO, Evans R, et al : Mechanism of experimental cancer cachexia. Interaction between mononuclear phagocytes and colon-26 carcinoma and its relevance to IL-6-mediated cancer cachexia.
J Immunol $148:$ 3674-3678, 1992.

24）坂本正洋，三笠桂一，澤木政好，他：原発性非 小細胞肺癌患者の癌悪液質に対する clarithromycinの有用性に関する検討. 日化療会誌 44 ： 879-882, 1996.

25）坂本正洋，三笠桂一，澤木政好，他：非小細胞 肺癌患者に対するclarithromycinの有用性に関 する研究一臨床指標, 生存期間および血清中IL6に関する検討一. 日化療会誌 $46: 87-89,1998$.

26) Zou JP, Yamamoto N, Takenaka $\mathrm{H}$, et al : Systemic administration of rIL-12 induces complete tumor regression and protective immunity : Response is correlated with a striking reversal of suppressed interferon $-\gamma$ production by anti-tumor $\mathrm{T}$ cells. Int Immunol 7 : 1135-1145, 1995.

27) $\mathrm{Mu} \mathrm{J}$, Zou JP, Yamamoto N, et al : administration of recombinant interleukin 12 prevents outgrowth of tumor cells metastasizing spontaneously to lung and lymph nodes. Cancer Res 55 : 4404-4408, 1995.

28) Brown DA, Kondo KL, Wong S-W, et al : Characterizatin of nuclear protein binding to the interferon $-\gamma$ promoter in quiescent and activated human T cells. Eur J Immunol 22 : 2419-2428, 1992. 


\title{
Effects of Clarithromycin on Expression of Cytokine mRNA in Spleen Cells of Mice Bearing Lewis Lung Carcinoma Cells
}

\author{
Katsuhiro Ueda, Keiichi Mikasa, Kaoru Hamada \\ Masahiro Sakamoto, Mitsuru Konishi, Kouichi Maeda \\ Toshimasa Majima, Eiji Kita* \\ and Nobuhiro Narita
}

The Second Department of Internal Medicine, Nara Medical University

*Department of Bacteriology, Nara Medical University

\begin{abstract}
Studies have showen that 14 -membered ring macrolides have various actions, in addition to antibacterial effects, in the long-term treatment of chronic lower respiratory tract infections. We reported that long-term treatment using clarithromycin (CAM), a 14-membered ring macrolide, was beneficial for patients with unresectable non smallcell lung cancer. In this study, we investigated the effects of CAM treatment on the expressions of cytokine mRNA in spleen cells of Lewis lung carcinoma cells in mice. Lewis lung carcinoma cells were injected into female C57BL/6 mice. Oral administration of CAM at a dose of $10 \mathrm{mg} / \mathrm{kg}$ was given once a day. Mice were divided to four groups according to whether tumor was injected or not, or whether mice were treated by CAM or not. Spleen cells were examined by RT-PCR after 14 days treatment. In the case of non-tumor bearing mice, there was no difference in expression of cytokine mRNA between mice treated or not treated with CAM. However, in the case of tumor-bearing mice, expressions of IL-4, IL-12p 40 , IFN- $\gamma$ mRNA increased and those of IL-6 mRNA decreased in CAM-treated mice compared to mice not treated with CAM. These results suggest that CAM might regulate the cytokine network in the tumor-bearing state.
\end{abstract}

